\title{
Innovative culturul and educational technologies of the museums in the south of Russia
}

\author{
Galina Ekinil ${ }^{1, *}$, Lyubov Gorgadze ${ }^{1}$, and Oksana Yuryeva $^{1}$ \\ ${ }^{1}$ Don State Technical University, Gagarin sq., 1, Rostov on Don, 344003, Russia
}

\begin{abstract}
This investigation is aimed at the analysis of museums of the South of Russia, the detection of their innovative organization. The article reveals the conception and essence of the museums, justifies the relevance and appropriateness of the development of innovative activities as a cultural and educational institution and an integral component of the regional tourism of the infrastructure of the South of Russia.
\end{abstract}

\section{Introduction}

Use and distribution of the conception «cultural and educational» museum activities, which appeared in the Russian museum studies in the late 1990, were connected with the formation of new methods and ways of working with visitors of different categories as well as a change in the attitude of society towards the museum, cultural and educational heritage when there occurs a re-thinking of conceptual models in the development of museum, the spread of a communicative approach.

Re-thinking of the content of the museum activities has led to a priority development of communicative and recreational functions of a modern museum. The main task of a modern museum as a socio-cultural institution is to create conditions for the development of social activity, the disclosure of spiritual potential of the individual, self-realization in the sphere of leisure and education. For this purpose a museum uses creative and non-standard methods of work with the public, informational and multimedia technologies, the innovative elements of entertainment and interactivity.

The goal of the work is to analyze the specifics of organizing and functioning of a museum network of the South of Russia (Southern Federal District or Southern Federal Region), the investigation of the impact of innovative activities of museums on the development of the regional tourism. The tasks are:

- to consider the museum as a social institute which performs socially significant functions in its region;

- to analyze cultural and informational environment of the region and the role of the museum;

- to highlight the target groups of museum communication and present the structure of communicative interaction of "Museum-City";

\footnotetext{
* Corresponding author: gekinil@mail.ru
} 
- to consider the traditional and innovative activities of museums of the Southern Federal District and identify trends in its development.

The structure of cultural environment of the region through its interaction with the museum can be analyzed in Fig. 1 .

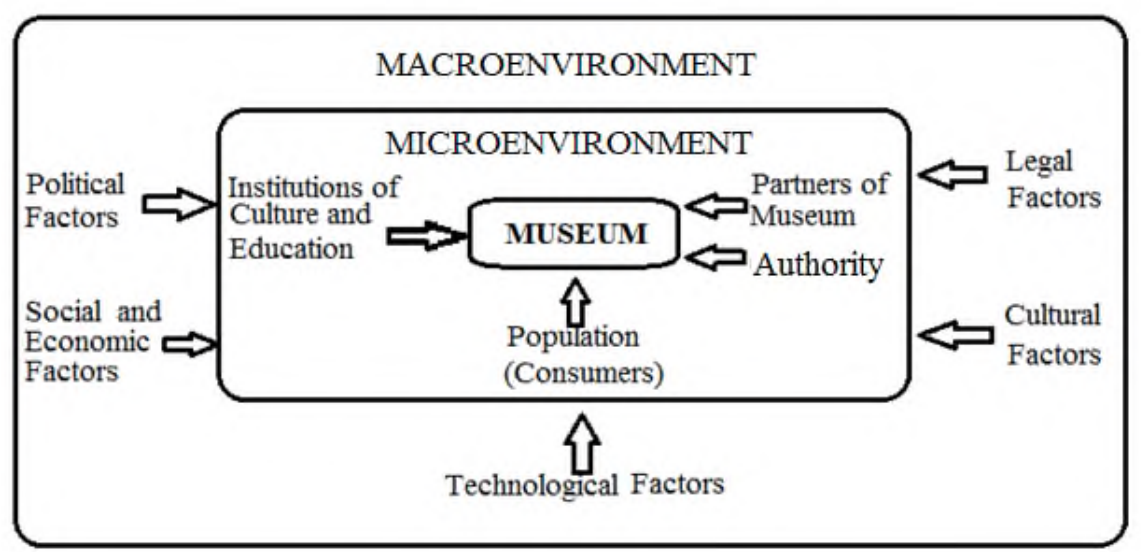

Fig. 1. The cultural and informational environment of the region.

Being located within the boundaries of a certain territory and region, museums solve tasks unusual for the other institutions.

- First of all, the museum presents itself the center of the scientific documentation. It is in the museum some material evidence that is documentation, of the development of history, culture and nature is concentrated, which, having become the museum objects carry genuine authentic information of great scientific and cultural significance.

- The museum is one of the centers of scientific and research activity in the region since the selection, research and use of museum items as exhibits requires a lot of research activity; the results obtained are often scientific discoveries in the cultural or natural processes.

- A museum is an institution of cultural representation of the region since in the museum exhibits presented in the expositions are the examples of cultural heritage. Museum exhibitions are a new cultural reality in which cultural norms are being accumulated dominating in a particular society at a certain time, and the activities of museum employees is carried out taking into account their professional culture.

- Documentary, scientific and cultural value of the museum makes it possible to consider it an educational and educational center carrying out the process of transferring cultural norms, the best traditions, the experience of generations taking into account the requirements the society puts forward in different historical periods.

\section{Materials and methods}

In modern conditions of reforming the Russian educational system various innovational processes are becoming more widespread. The development of computer technology, its introduction into social practice resulting from this changes of the activities and psychology of a person, all this makes up the essence of the process of computerization which plays the key role in the formation of the of information-type society. Thanks to the invention and rapid improvement of electronical and computing technology many plans related with the development of artistic, informational, scientific, communicative activities of the museum began to be implemented. The approbation and implementation of innovations in the 
system of museum education should be considered as a continuous process, as a component of everyday cultural and educational activities of museums.

The appearance of computers in the life of museums has actualized the problem of using historical knowledge, especially since the informational technologies makes it possible to more extensively collect, store, distribute and process museum information. The property of interactivity in the museum is also inherent in a multimedia resource which is also the manifestation of complex interaction of media which is being formed within virtual threedimensional space and it becomes a continuous, endless museum process. The emergence of new technics makes it possible to convey the content of the museum with the help of various means of information that are available for perception with various human senses and even through interactive intercourse with the audience. When identifying the specifics of innovational activities of museums of the South Federal District included the tourism and hospitality industry, on the one hand, it was necessary to analyze the works in the field of education in tourism of such authors, as: Jianwei Qian, Rob Law, Xinjian Li 2019 [1], Hyun Jeong Kim, Miyoung Jeong 2018 [2], Ana Dias Daniel, Rui Augusto Costa, Mariana Pita, Carlos Costa 2017 [3], Valentina Ndou Gioconda, Mele Pasquale, Del Vecchio 2019 [4], Jude Walker, Vimbiso Ngara Manyamba 2020 [5], Carl Behnke, Soobin Seo, Kay Miller 2014 [6], Yaniv Belhassen, Kellee Caton 2011 [7], Cathy H.C.Hsu 2018 [8], M. Joppe, S. Elliot 2015 [9].

On the other hand, the peculiarities of innovations in tourism and hospitality induistries were studied, reflected in the works: N.A. Zaitseva, I.V. Goncharova, M.E. Androsenko (2016) [10], N.Y. Goryushkina, D.V. Shkurkin, A.S. Petrenko, S.Y. Demin, N.S. Yarovaya 2016 [11], S. Wang, K.Hung 2015 [12], Ivanov V., Popov S., Dontsov N., Ekinil G., Oleynikova Ju., Denisenko Ju. 2020 [13], Valeria Provotorina, Lyudmila Kazmina, Antonina Petrenko, Galina Ekinil 2020 [14].

To the methods of research of innovations in education the works are devoted of such foreign authors, as: A. Mai Walder, 2017[15], J.Chun-Chung Chow, Cheng Ren, Brenda Mathias, Jiaying Liu 2019 [16], Meiju Keinänen, Jani Ursin, Kari Nissinen 2018 [17], Viv Ellis, Ann Childs 2019 [18], Nicole C.Jackson 2019[19].

Among general methodological approaches applied in the cultural and educational activities of museums, one should highlight systematic, institutional and integrated approaches. They make it possible to study the trends and process that take place in the museum education. In the course of investigation, a typological approach is used which allows to characterize not only the current tendencies, problems and contradictions of transformation of museum education, but also to identify possible prospects for this process. Among the main methodological approaches applied to cultural and educational activities of museums, one should highlight systematic, institutional and integrated approaches. They provide the opportunity to study trends and process which take place in museum education. In the course of this study, a typological approach is also applied which allows to characterize not only the current trends, problems and contradictions of transformation of museum education, but also to identify possible prospects for this process. The scientific provisions, conclusions and recommendations contained in the article are based on the use of combined methods of historical and logical analysis.

\section{Results}

The Southern Federal District (SFD) is the federal district of the Russian Federation (RF) in the South of its European part. The Southern Federal District includes 3 republics, 3 regions, 1territory and 1 city of federal significance, with the population of 16466084 people $(11,22 \%$ from the population of RF as of January,1 2020) and an area of 447821 $\mathrm{km}^{2}(2,61 \%$ from the area of territory of RF). 
In the west and north-west, the territory of the district along the waters of the Black and Azov Seas as well as on land, borders on the Ukraine, in the west it borders on Kazakhstan. In the south it borders on Abkhazia and North-Caucasus Federal District, in the North it borders on the Central and Volga Federal Districts.

In the east the Federal District is bounded by the Caspian Sea, while in the East - by the Black and Azov Seas.

The administrative body of the UFD is the city of Rostov-on-Don.

Table 1. Of the museum network of the South of Russia

\begin{tabular}{|l|l|l|l|}
\hline № & Subject UFD & Capital & $\begin{array}{l}\text { The number } \\
\text { museums }\end{array}$ \\
\hline 1 & The Republic of Adygea & Mikop & 9 \\
\hline 2 & The Astrakhan Region & Astrakhan & 16 \\
\hline 3 & The Volgograd Region & Volgograd & 24 \\
\hline 4 & The Republic of Kalmykia & Elista & 8 \\
\hline 5 & The Krasnodar Territory & Krasnodar & 45 \\
\hline 6 & The Rostov Region & Rostov-on-Don & 63 \\
\hline 7 & The Republic of Ingushetia & Magas & 7 \\
\hline 8 & Kabardino-Balkaria & Nulchik & 17 \\
\hline 9 & Dagestan & Makhachkala & 35 \\
\hline 10 & Karachayevo-Cherkessia & Cherkessk & 7 \\
\hline 11 & The North of Osetia & Alania & 9 \\
\hline 12 & Chechnia & Grozny & 10 \\
\hline & & & $\mathbf{2 5 0}$ \\
\hline
\end{tabular}

Based on this table, we will build a diagram, let's call it Fig.2.

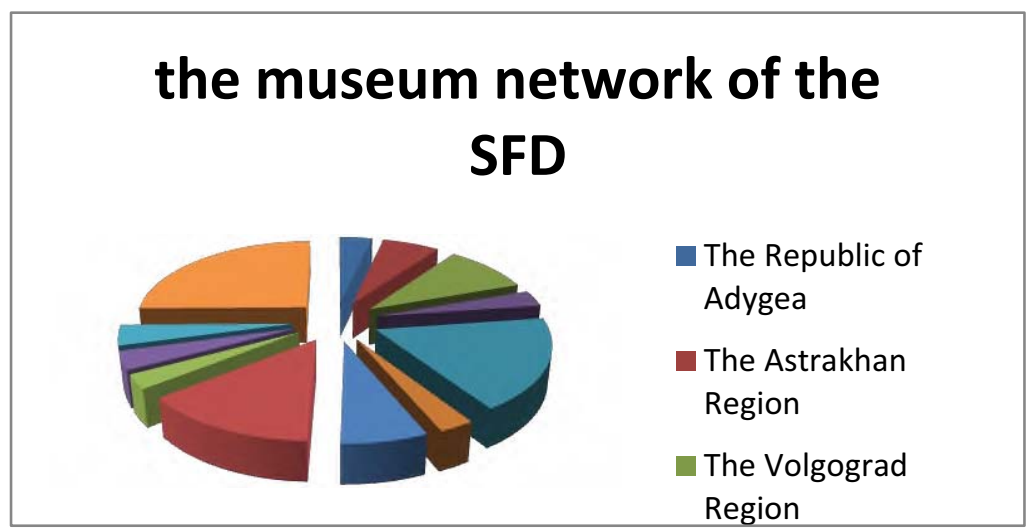

Fig. 2.The museum network of the SFD

The museum network of the South of Russia consists of 266 museums (on average, 1 museum accounts for 61902 inhabitants). The largest number of museums is located in the administrative center of the Southern Federal District - Rostov-on-Don. On the territory of the Rostov Region there are 63 museums, including 1 federal one: "The State MuseumReserve of M.A. Sholokhov"; 15 regional, 27 municipal ones, and 1 memorial one.

For intelligentsia of Rostov-on-Don, regular visits to museums have become the norm for family leisure on week-ends. The significant part of those who visit museums on average 14-16 times a year is young parents with children of primary and secondary school age. 
It is fundamentally important that communication with museum began to prevail in the structure of public leisure not only in in the regional center but also in cities such as Novocherkassk, Taganrog, Shakhty, and a number of others. In respectively small towns of the Rostov Region, museums should constantly take into account the needs of residents of their region, update expositions on regular basis, offer visitors new forms of historical, cultural and artistic education.

The annual attendance of museums of the Rostov Region is more 800 thousand people, for comparison, the number of readers in libraries makes up 689,5thousand people.

The attendance of state museums in the Rostov Region has grown up by $5 \%$ over the last 3 years. This has become possible due to the expansion of museum areas and increase in funds, as well as the expansion of cooperation of regional museums with tourist and information centers.

For 5 years, the main fund of museums has increased by 49thousand exhibits, and the area of museum spaces has enlarged by 5 thousand square meters.

The regional organizations are actively developing cooperation with museums from other regions of the Russian Federation. During the recording period, there were held 19 exchanged exhibitions with the museums from other subjects of the federation.

Since 2019, the Tanais Museum-Reserve and the Azov Museum-Reserve have been included in the federal project "The Golden Ring of Bosporus Kingdom". And the main event of the year 2020 has become the opening of national military- historical museum complex of the Great Patriotic War "Sumbek Hights".

The number of conducted excursions is gradually growing, which to a large extent positively characterizes the quality level of information services for visitors, among whom are mainly schoolchildren and students.

To meet recreational needs of the modern consumer of cultural services, the museums of the South of Russia use such forms of cultural and educational activities, as concerts, balls, museum festivals or theatrical performances, shows with the participation of not only professional actors but also the visitors themselves.

In museum and pedagogical practice, role-playing games are actively used which are considered to be one of the most efficient and promising forms of cultural and educational activities aimed at the developing of historical consciousness. This method of interacting with the public based on role behavior makes it possible to immerse oneself into a specific environment created by museum educators.

The Rostov museum "Russia-my history" began to work in October 2018. In terms of construction works, it has become one of the most expensive one in the Russian Federation. For 5 months of its work it had over 100 thousand visitors which allowed it to reach the level of attendance that of the Russian Regional Museum of Local Lore.

With the development of mass media, mediated experience is becoming increasingly important. The most important mediated human experience is art and culture making a considerable significance to the formation of a spiritual and value world of man.

Let's single out the target groups of museum communications in the region in Table 1:

Table 1. Target groups of museum communications in the region

\begin{tabular}{|l|l|}
\hline $\begin{array}{l}\text { Necessary interaction groups for the } \\
\text { development of museum communications }\end{array}$ & \multicolumn{1}{|c|}{ Terms of Interaction } \\
\hline $\begin{array}{l}\text { Authorities, local self-government, } \\
\text { committees, ministries }\end{array}$ & $\begin{array}{l}\text { Drawing attention to the museum and culture in } \\
\text { general. Control over the activities of the museum }\end{array}$ \\
\hline $\begin{array}{l}\text { Real visitors and consumers of museum } \\
\text { services }\end{array}$ & $\begin{array}{l}\text { Increase in attendance, opportunities of } \\
\text { communication with a museum, involvement in } \\
\text { museum life }\end{array}$ \\
\hline Tourists (organized, single) & $\begin{array}{l}\text { Increasing of flow of tourists, increasing } \\
\text { attractiveness of the region }\end{array}$ \\
\hline Mass Media Representatives & \begin{tabular}{l} 
Interaction in the promotion of museum products, \\
\hline
\end{tabular}
\end{tabular}




\begin{tabular}{|l|l|}
\hline & $\begin{array}{l}\text { services. Coverage of museum life, presentation of } \\
\text { the necessary information to mass media. }\end{array}$ \\
\hline $\begin{array}{l}\text { Representatives of creative organizations, } \\
\text { associations }\end{array}$ & $\begin{array}{l}\text { Organization of joint projects, programs, } \\
\text { competitions }\end{array}$ \\
\hline Charitable public organizations & $\begin{array}{l}\text { Joint work to improve the social and cultural life of } \\
\text { the city }\end{array}$ \\
\hline Sponsors (legal entities and individuals) & Support and development of museum activities \\
\hline Mediators ((legal entities and individuals) & Proposals for organizing exhibitions, events \\
\hline Competitors (galeries, museums, exhibitions) & $\begin{array}{l}\text { Proposals for cooperation, information exchange, } \\
\text { interaction }\end{array}$ \\
\hline Educational Institutions & $\begin{array}{l}\text { Joint work on educational process of youth } \\
\text { development. Training personnel for work in the } \\
\text { museum sphere, information exchange }\end{array}$ \\
\hline
\end{tabular}

Currently, without a doubt, one can talk about the flourishing of museum business. The role of museum begins to increase, more and more interested people come to the museum. The museum got involved into solving super task facing the society which is to release positive social energies by creating favourable conditions for this. The social status of museums is increasing, and, in this regard, the interest in them is also increasing. Museums are opening everywhere and their creation is the indicator of the development of self-awareness of society. Through the museum one of the most important needs of society is realized that is to conserve the memory about its history, its heritage. Many institutions and administrative bodies seek to learn the history of their organization and create temporary exhibitions, offices, stands, and sometimes and museums dedicated to the history of the organization. Likewise cities are not only a collection of buildings and structures, museums are not also limited to the storage of their monuments and relics. The impression of a city is made up of many constituents. These are leading industrial and cultural organizations with their own unique history, the monuments of architecture, and these are people who have created the material and spiritual values.

Table 2. The scheme of communication interaction "Museum-City"

\begin{tabular}{|l|l|}
\hline \multicolumn{1}{|c|}{ Museum - City } & \multicolumn{1}{c|}{ City - Museum } \\
\hline - study and preservation of historical and & - maintaining of material and technical base \\
cultural heritage of the region; & of the museum; \\
- presentation of history and culture of the & - assistance in training of professional staff \\
city and region; & for the museums; \\
- organization of leisure and "free time" for & - legal regulation of activities of museums \\
residents of city; & within a region and city npaBoBoe; \\
- inclusion of a person in the "cultural & - museum propaganda; \\
space" of the city; & - insuring of safety and security of museum \\
- involvement residents in creative activities; & collections; \\
- formation of culture, morality, decency, & - promoting the attraction visitors to the \\
mercy and patriotism of the inhabitants of & museum; \\
the region; & - motivation of museum workers in the form \\
- meeting of needs of tourists coming to the & of grants and incentives; \\
city; & - creating of investment climate for investors \\
- increasing of investment attractiveness of & contributing to the development of the. \\
the city; & \\
- contribution to the creation of new jobs; & \\
- the museum makes the image of the city \\
more multifaceted and increases its
\end{tabular}

Thus, communication interaction in the system "Museum-City" demonstrated that the museum today is able to form and develop the image of its city in a more multifaceted way, which contributes to increasing its authority, emphasizes its uniqueness in the eyes of the residents and promotes public cohesion. 
Museum communication in the region contributes to the activation of the processes of personality formation, development of the creative abilities, socialization and the development an active life position. One of the tasks of museum communication is creating prerequisites and conditions for activating of visitors, in particular for improving contacts with museum objects as sources of knowledge, emotions, esthetical impressions, and creation of effect of immersion into the cultural environment.

\section{Discussion}

The information approach that has emerged in recent years in science and various fields of practical activities of museums takes into account not only the quantitative indicators (volume) of museum information, but also its qualitative aspect, to determine which the conception "information value" is used, which is the main criterion for its selection for the museum.

The scape of dissemination of information technologies in museum activities deepens the process of globalization and in the most serious way affects the nature of cultural life of society, opening up broad opportunities for comprehending traditional culture and creating its new forms. It should be remembered that virtual realities of the museum are only a means of modelling of possible solutions but they do not replace real life as well as genuine works of arts. Thus, we are talking about the nature of interaction between bearers of traditional and informational cultures.

The formation of this interaction is reflected in the pedagogical communication of the museum, since the museum throughout all its historical development accumulates various forms of work with people, such as, intercourse, conversation, dialogue, lectures, etc.

The formation of cultural heritage, that is, the creation of cultural fund of the South of Russia is extremely important today, and this process is impossible without accumulation of information and intellectual potential using Net-technologies, so-called info link. There are two types of info link - synchronous and diachronic. The first one assumes the possibility of establishing feedback between a subject and an object within the same time interval. In the second case, information is transferred from the previous generations to the subsequent ones. The diachronic info link can be considered as a specific mechanism of accumulation and transference of social experience.

With the help of information technologies the museum is able to provide for potential visitors with the information about the collections and the most significant monuments of the museum endowed with accompanying text information of a general nature; about forms and contents of socio-cultural activities of the museum (new exhibitions, educational programs, the cycles of excursions and lectures, the work of clubs, studious, etc.)

In general, the use of modern technologies does not only aim to replace communication with the museum but to organize better and more efficient communication of visitors with cultural values.

Informational policy of the museum should cover the matters of intellectual property, compliances Data Protection Law (for the relevant country) or other similar acts and the position of administration of the museum regarding participating in joint databases or other ways of disseminating of museum information, especially the pictorial one. The transition to a presentation of digital information including visual information radically changes our understanding of the possibilities of reproduction.

Practical issues related to the opening of the access at least to some areas of the museum databases and with control of this access (if such is possible or desirable) are currently very widely discussed. Increasing the access of the public to museum collections should, of course, be welcome but it also raises the risk of misuse of images, copyright infringement or loss of potential income, now or in the future. Contemporary art museums are 
particularly challenged as far as living artists may demand their shares of profit from the dissemination of the information or images.

The information policy should clearly express the obligation of the museum to maintain accurate and comprehensive documentation of its collection, to preserve and provide excess to all necessary information indefinitely, and to insure that the public has acceptable access to museum information. Some information (for example, about the cost of various storage facilities of and insurance amounts) should, as before, remain confidential.

The undoubted advantages of computerization of the process in the communication sphere of the museum can be considered:

- the creation of models for the search and evaluation of the museum information allowing to collect sufficiently large amount of data about audiences, artifacts and mass media;

- the possibility to transform the obtained data into variant constructions for the use of certain combinations of mass media;

- the possibility to assess the effectiveness and cost of various channels and museum communication;

- the possibility to systematically select and transform the data as well as test them without using real resources;

- consideration of unforeseen circumstances.

It should also be noted that the internet technologies allow a manager working in the communication field to significantly reduce the time spent on preparing of a business plan and also improve the process of processing and archiving museum information. Computerization in a museum did not only expand the technological opportunities, but transferred the essence of museum communications into a new much higher quality of communication. All the previously known limiting factors- the problems of the speed of transfer of museum information, accessibility, mass character, interactivity, reliability and others - either significantly reduced the threshold of limitation, either, on the contrary, acquired the characteristics of an informational advantage over other institutions of culture.

The museums of the South of Russia have become the applicants of the national project "Digital Culture": they submitted applications to be equipped with the multimedia guides using augmented reality technology.

The state and municipal museums of Russia are planned to be equipped with these guides as part of the implementation of the regional national project "Digital Culture". Currently, 10 Don cultural institutions of culture have sent the applications for the equipment, in particular, such large museums, as the Azov Historical Archeological and Paleontological Museum-Reserve and the Rostov Regional Museum of Local Lore.

To work a multimedia guide, you need not only Internet, but also Artefact mobile application which was developed with the support of the Ministry of Culture and the project "Kultura.RF". If a visitor downloads it, he or she by pointing a smartphone to the exhibit from any angle will learn including in an audio format all interesting details about it.

So, Azov Historical Archeological and Paleontological Museum-Reserve intends to use such a guide as part of its exposition "The Treasures of Eurasian Nomads" which contains unique ancient works of art associated with the Bosporus Kingdom. This will contribute to the creation of the tourist route "The Golden Ring of the Bosporus Kingdom", which will appear in the South of Russia, it will run through the territory of the Rostov region, Crimea and Kuban.

The visitor of the museum will be able to study the subject in detail due to the active points which will be displayed on the screen when the phone is hovering.

For example, the bracelet, which is 2000 years old, found in Sarmatian burial can be shown being closed, clicked and open. The objects can even be demonstrated as they were before the restoration, in the moment of their discovering, if the photographs of the exhibit were taken before the restoration. 
The multimedia guide will be able to replace the guide and even tell more, because the excursion specialist does not always have time to delve into all the details.

Thus, the Ministry of Culture of the region and the management of the museum are able to take part in this project. From the technical standpoint, the museums of the Rostov Region have such an opportunity. From the methodological recommendations of specialists on filling out this platform, this work has been organized by the Ministry and the leading museums, in particular, by the Azov one.

\section{Conclusions}

Net-technologies open up opportunities for creating museums and expositions of a virtual format, enable to include in the creative process the multimedia equipment which is endowed with the ability to erase the barriers: educational, linguistic, cultural. Nettechnologies can and must contribute and help to solve the tasks of cultural accumulation and development of national cultural heritage. The process of broadcasting of the cultural heritage or information interaction is also impossible without the cultural and creative participation of the museums of the South of Russia, which are entrusted with the functions of creating a cultural heritage: selection, accumulation and broadcasting.

Net-technologies enable nowadays to start to create new models of global history of the culture of peoples in a media space. UNESCO is already implementing the programs "Information for All", "Memory of the World" and others. Therefore, with an appropriate cultural policy and the creativity of the conditions for the development of national forms of art, Net-technologies are able to give a new impetus to the development not only innovative but and traditional as well. Expanding the types of activities of the museums of the South of Russia, while participating in all these innovative projects (national and international), as well as increasing the list of services provided by museums will contribute to the development of the regional tourism and will also contribute to its further development.

The increase in the innovative types of activities of the museums of the South of Russia, from one side, will ensure the conservation of the historical heritage, support of national traditions and culture, folk crafts and trades, local customs and folklore. From the other hand, the innovative projects make it possible to consider museums an educational and educational center, carrying out the process of transferring cultural norms, the best traditions, the experience of generations while taking into account the requirements which the society puts forward in various historical periods.

\section{References}

1. J. Qian, R. Law, X. Li, Journal of Hospitality, Leisure, Sport \& Tourism Education, 24, 120-129 (2019) https://doi.org/10.1016/j.jhlste.2019.02.003

2. H. J. Kim, M. Jeong, Tourism Management Perspectives, 25, 119-122 (2018) https://doi.org/10.1016/j.tmp.2017.11.025

3. A. D. Daniel, R. A. Costa, M. Pita, C. Costa, Journal of Hospitality and Tourism Management, 30, 65-72 (2017) https://doi.org/10.1016/j.jhtm.2017.01.002Get rights and content

4. V. N. Gioconda, M. Pasquale, D. Vecchio, Journal of Hospitality, Leisure, Sport \& Tourism Education, 25, 100175 (2019) https://doi.org/10.1016/j.jhlste.2018.10.003

5. J. Walker, V. N. Manyamba, Journal of Hospitality, Leisure, Sport \& Tourism Education, 26, 100213 (2020) https://doi.org/10.1016/j.jhlste.2019.100213Get rights and content 
6. C. Behnke, S. Seo, K. Miller, Tourism Management, 42, 271-281 (2014) https://doi.org/10.1016/j.tourman.2013.12.010

7. Y. Belhassen, K. Caton, Tourism Management, 32, 1389-1396 (2011) https://doi.org/10.1016/j.tourman.2011.01.014

8. C. H. C. Hsu, Tourism Management Perspectives, 25, 181-183 (2018) https://doi.org/10.1016/j.tmp.2017.11.022

9. M. Joppe, S. Elliot, Journal of Teaching in Travel and Tourism, 15, 201-203 (2015)

10. N. A. Zaitseva, I. V. Goncharova, M. E. Androsenko, International Journal of Economics and Financial Issues, 6(1), 288-293 (2016)

11. N. Y. Goryushkina, D. V. Shkurkin, A. S. Petrenko, S. Y. Demin, N. S. Yarovaya, International Review of Management and Marketing, 6(S6), 207-213 (2016)

12. S. Wang, K. Hung, International Journal of Hospitality Management, 48, 92-101 (2015)

13. V. Ivanov, S. Popov, N. Dontsov, G. Ekinil, Ju. Oleynikova, Ju. Denisenko, E3S Web of Conferences. XIII International Scientific and Practical Conference "State and Prospects for the Development of Agribusiness - INTERAGROMASH 2020”, 175, 05023 (2020)

14. V. Provotorina, L. Kazmina, A. Petrenko, G. Ekinil, E3S Web of Conferences. XIII International Scientific and Practical Conference "State and Prospects for the Development of Agribusiness - INTERAGROMASH 2020”, 175, 10002 (2020)

15. A. M. Walder, Studies in Educational Evaluation, 54, 71-82 (2017) https://doi.org/10.1016/j.stueduc.2016.11.001

16. J. C.-C. Chow, C. Ren, B. Mathias, J. Liu, Children and Youth Services Review, 101, 217-224 (2019) https://doi.org/10.1016/j.childyouth.2019.04.008Get rights and content

17. M. Keinänen, J. Ursin, K. Nissinen, Studies in Educational Evaluation, 58, 30-36 (2018) https://doi.org/10.1016/j.stueduc.2018.05.007Get rights and content

18. V. Ellis, A. Childs, Teaching and Teacher Education, 77, 277-28 (2019) https://doi.org/10.1016/j.tate.2018.10.020Get rights and content

19. N. C. Jackson, Business Horizons, 62, 761-772 https://doi.org/10.1016/j.bushor.2019.08.002Get rights and content 